\title{
Pendampingan Kegiatan Pengelolaan Sampah Kertas di SD GMIT Ende 4
}

\author{
Nining Sariyyah ${ }^{1}$, Manggu Ngguna Raji ${ }^{2}$, Yuliani Sepe Wangge ${ }^{3}$, Agnes Remi Rando ${ }^{4}$, \\ Maria Purnama Nduru ${ }^{5}$, Berty Sadipun ${ }^{6}$, Felix Welu ${ }^{7}$ \\ ${ }^{1-7}$ Prodi PGSD Universitas Flores, Ende, NTT \\ ${ }^{1}$ sariyyah.nining@gmail.com
}

\begin{abstract}
ABSTRAK
Isu tentang sampah merupakan hal yang harus ditangani secara serius. Mengingat banyak dampak negatif yang ditimbulkan oleh sampah, perlu dilakukan berbagai upaya-upaya dalam pengelolaannya. Salah satunya melalui proses daur ulang menjadi berbagai jenis karya kerajinan tangan. Upaya ini dilakukan oleh dosen dan mahasiswa program studi PGSD Universitas Flores. Program ini juga secara rutin disosialisasikan ke sekolah dasar yang ada di kabupaten Ende, salah satunya di SD GMIT Ende 4.
\end{abstract}

Kata kunci: Pengelolaan Sampah Kertas

\section{PENDAHULUAN}

Sampah merupakan material sisa yang sudah tidak terpakai lagi. Menurut Azwar sampah adalah sesuatu yang tidak dapat dipakai lagi, yang tidak disenangi dan harus dibuang (Suryani, 2014)). Sampah terdiri atas sampah organic, sampah yang dapat didaur ulang dan sampah yang tidak dapat di daur ulang.

Menurut Gilbert (dalam Artiningsih, 2008) sumber-sumber sampah dapat berasal dari pemukiman penduduk, tempat umum dan perdagangan, sarana pelayanan masyarakat milik pemerintah, industri dan pertanian. Sampah pemukiman penduduk cenderung bersifat organic seperti sisa makanan yang masih basah. Sampah tempat umum dan perdagangan umumnya berasal dari pertokoan dan pasar seperti sampah kering, plastik, kertas, kaleng, sisa makanan dan lain-lain. Sedangkan sampah kering dan sampah basah sering dihasilkan pada tempat yang merupakan sarana pelayanan masyarakat. Sampah pertanian dapat beupa makanan, pupuk maupun bahan pembasimi serangga tanaman.

Sampah dapat dihasilkan di berbagai tempat sesuai dengan aktivitas yang dilakukan manusia.. Banyaknya sampah yang dihasilkan menyebabkan semakin terbatasnya tempat penampungan sampah. Morgan menyatakan bahwa permasalahan sampah adalah kemudahan masyarakat dalam membuang sampah (Fadhilah dkk, 2011). Begitu mudahnya sampah dihasilkan mengakibatkan banyak hal negatif yang ditimbulkan seperti masalah kesehatan, merusak pemandangan dan bau yang tidak sedap. Sehingga diperlukan upaya-upaya penanganan serius untuk meningkatkan kesadaran masyarakat dalam mengurangi jumlah sampah.

Kertas merupakan jenis sampah yang lazimnya ditemukan di sekolah dan sarana edukasi lainnya. Walaupun dunia telah mengalami kemajuan digitalisasi, namun penggunaan kertas di Indonesia masih sangat tinggi. Mengingat sumber pembuatan kertas dewasa ini berasal dari selulosa tumbuhan (pulp), penggunaan kertas dan sampah yang dihasilkan juga ikut menyumbangkan efek global warming.

Berdasarkan data resmi dari The UN Food \& Agriculture Organization's (FAO) tahun 2001-2007 menunjukkan pertumbuhan produksi kertas dunia sebesar 3,05\%. Perkiraan dalam dekade berikutnya berada antara $2 \%$ sampai $3,5 \%$ pertahun. Pertumbuhan ini meningkatkan konsumsi kayu bulat sebagai bahan utama kertas sebesar 1 sampai 2 juta hektar per tahun. Peningkatan kebutuhan tersebut juga menaikkan laju deforestasi dan kerusakan hutan (Hardiyanti, Syamsu dan Roliadi, 2010). Hal ini memberikan efek terhadap peningkatan gas $\mathrm{CO} 2$ sebagai salah satu penyebab pemanasan global. Untuk itu, sampah kertas perlu ditangani secara serius. Salah satu metode pengolahan sampah adalah 3R, yaitu reduce, recycle ataupun reuse.

Kurniati dan Rizal (2011) menyatakan Reduce adalah mengurangi semaksimal mungkin kegiatan yang akan menghasilkan sampah. Reuse merupakan kegiatan menggunakan kembali barang atau bahan yang 
telah dipakai. Sedangkan recycle adalah mendaur ulang kembali suatu produk. Mengelola sampah kertas menjadi berbagai macam prakarya merupakan salah satu bentuk kegiatan recycle. Upaya tersebut dapat diterapkan ke sekolah-sekolah sebagai sarana untuk mengedukasi generasi penerus tentang pentingnya masalah penanganan sampah. Oleh karena itu, dilakukanlah kegiatan pengabdian masyarakat dengan tujuan untuk memberikan pemahaman kepada siswa tentang sampah kertas dan pengolahannya menjadi berbagai produk prakarya. Kegiatan tersebut dilaksanakan di SD GMIT Ende 4 sebagai salah satu sekolah dasar favorit di kabupaten Ende, NTT.

\section{METODE PENELITIAN}

Metode yang digunakan dalam kegiatan ini adalah metode ceramah dan praktikum. Metode ceramah digunakan untuk memberikan pemahaman kepada siswa tentang kertas yang terdiri atas, asal usul kertas, cara pembuatannya, masalah yang ditimbulkan sampah kertas dan dampaknya terhadap lingkungan, serta bagaimana mengolah sampah kertas. Sedangkan Metode praktikum ditujukan untuk memberikan praktik secara langsung tentang cara mengolah limbah kertas menjadi produk prakarya.

Luaran yang diharapkan dari kegiatan ini yakni dapat menghasilkan produk prakarya yang berasal dari sampah kertas. Untuk mengetahui respon siswa terhadap kegiatan tersebut, disiapkan angket yang berisikan 6 item pernyataan. Angket dianalisis dengan membandingkan perolehan persentase per item pernyataan dengan merujuk pada Tabel 1 .

Tabel 1 Kriteria Penilaian Angket Respon Siswa

\begin{tabular}{cc}
\hline Nilai $(\%)$ & Kriteria \\
\hline $92-100$ & Sangat Baik \\
$75-91$ & Baik \\
$50-74$ & Cukup Baik \\
$25-49$ & Kurang Baik \\
$0-24$ & Tidak Baik \\
\hline
\end{tabular}

\section{HASIL \& PEMBAHASAN}

Untuk melancarkan kegiatan, tim pengabdian masyarakat terlebih dahulu menghubungi pihak sekolah untuk mengurus izin penyelenggaraan kegiatan. Setelah memperoleh kesepakatan, pelaksanaan kegiatan ini pun dilaksanakan sebanyak dua kali pertemuan yakni pada hari sabtu 17 November 2018 dan 24 November 2018. Pihak sekolah juga bersedia memfasilitasi dengan menyiapkan perangkat pengeras suara dan berbagai jenis sampah kertas seperti kertas koran dan kertas HVS. Kertas tersebut yang akan digunakan untuk membuat berbagai jenis prakarya. Kegiatan dilaksanakan secara outdoor di alun-alun SD GMIT Ende 4. Peserta kegiatannya adalah siswa-siswi kelas V SD GMIT Ende 4 sebanyak 98 orang, 7 orang mahasiswa dan 7 orang dosen prodi PGSD Uniflor beserta guru-guru SD GMIT Ende 4.

Pada Tanggal 17 November 2018, tim dosen mengawali kegiatan dengan ceramah. Secara bergiliran ceramah disampaikan kepada siswa tentang asal usul kertas, cara pembuatannya, masalah yang ditimbulkan sampah kertas dan dampaknya terhadap lingkungan, serta bagaimana mengolah sampah kertas. Kegiatan ceramah menghabiskan waktu kurang lebih satu setengah jam yang kemudian dilanjutkan dengan kegiatan praktikum.

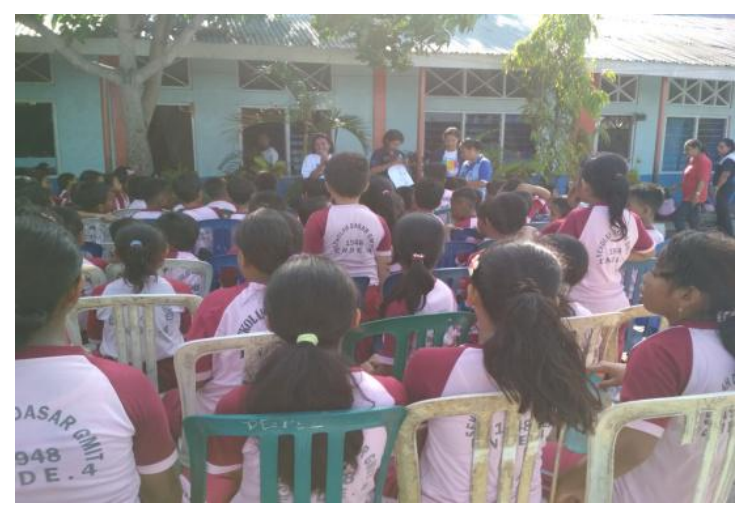

Gambar 1. Kegiatan Ceramah

Kegiatan praktikum dilakukan dengan membagi kelompok kerja sebanyak 7 tim. Tiap tim terdiri atas 1 orang dosen pendamping, mahasiswa dan 13 siswa. Sampah kertas yang telah dikumpulkan pihak sekolah kemudian dibagikan pada kelompok tersebut. Sampah tersebut diolah melalui proses menggunting dan menggulung kertas. Gulungan-gulungan kertas tersebut kemudian dibentuk menjadi berbagai macam produk seperti pot bunga, tempat pensil, bunga dll. 


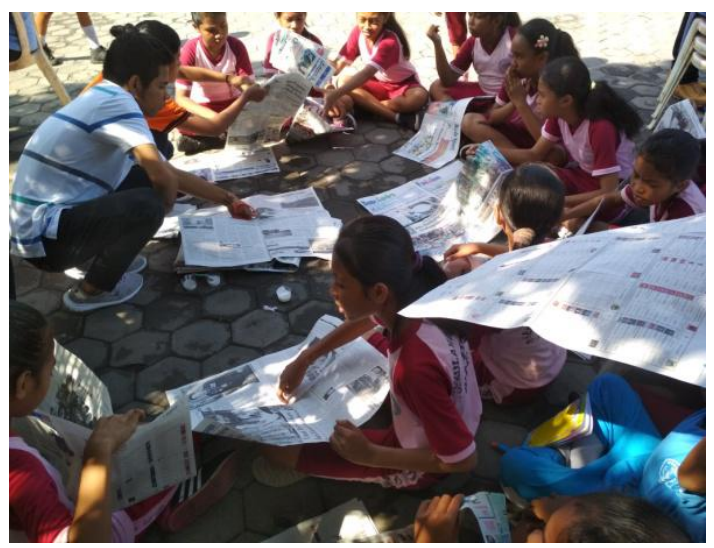

Gambar 2. Siswa membuat Gulungan Kertas

Kegiatan praktikum dilanjutkan pada pertemuan 2, tanggal 24 November untuk proses finishing produk. Finishing dilakukan dengan memberikan warna pada produk yang sudah jadi. Kegiatan hari terakhir tersebut mengalami kendala cuaca karena dilaksanakan secara outdoor. Siswa-siswi yang semula berada di alun-alun pun dipindahkan ke terasteras ruang kelas untuk menghindari hujan. Kegiatan diakhiri dengan presentasi produk prakarya berbasis sampah kertas oleh masingmasing kelompok. Selain itu juga dilakukan foto bersama dimana peserta memegang produk karya masing-masing. Pada akhir

Tabel 2 Angket respon peserta kegiatan

\begin{tabular}{|l|l|c|}
\hline No & \multicolumn{1}{|c|}{ Pernyataan Angket } & $\begin{array}{c}\text { Persentase } \\
(\%)\end{array}$ \\
\hline 1 & $\begin{array}{l}\text { Prakarya yang dikerjakan dalam kegiatan pelatihan ini } \\
\text { merupakan hal yang baru bagi saya }\end{array}$ & 87 \\
\hline 2 & $\begin{array}{l}\text { Pengetahuan dan keterampilan yang diberikan dalam kegiatan ini } \\
\text { sangat bermanfaat untuk saya }\end{array}$ & 91 \\
\hline 3 & $\begin{array}{l}\text { Dengan pelatihan ini saya merasa memperoleh gambaran } \\
\text { mengenai penanganan sampah di sekolah maupun di rumah }\end{array}$ & 87 \\
\hline 4 & $\begin{array}{l}\text { Pelatihan ini memacu saya untuk ingin belajar lebih dalam lagi } \\
\text { mengenai prakarya berbasis bahan bekas /sampah }\end{array}$ & 88 \\
\hline 5 & Secara umum saya merasa puas mengikuti kegiatan pelatihan ini & 84 \\
\hline 6 & Menurut saya alokasi waktu dalam kegiatan ini sudah sesuai & 71 \\
\hline \multicolumn{1}{|c|}{ Rata-rata (\%) } & 85 \\
\hline
\end{tabular}

Berdasarkan Tabel 2 perolehan persentase pada pernyataan 1 , pernyataan 3 , pernyataan 4 dan pernyataan 5 menunjukkan respon siswa dengan criteria baik. Sedangkan item 2 menunjukkan respon siswa dengan criteria sangat baik. Namun pernyataan 6 mengenai alokasi waktu, mencapai persentase terendah yakni $71 \%$ dengan kriteria respon cukup baik. Hal ini apat dimaklumi karena kegiatan ini cukup disambut dengan antusias oleh siswa. Namun alokasi waktu yang diberikan masih kurang. Secara keseluruhan, rata-rata siswa menunjukkan repon yang baik kegiatan juga disebarkan angket untuk mengetahui respon siswa.

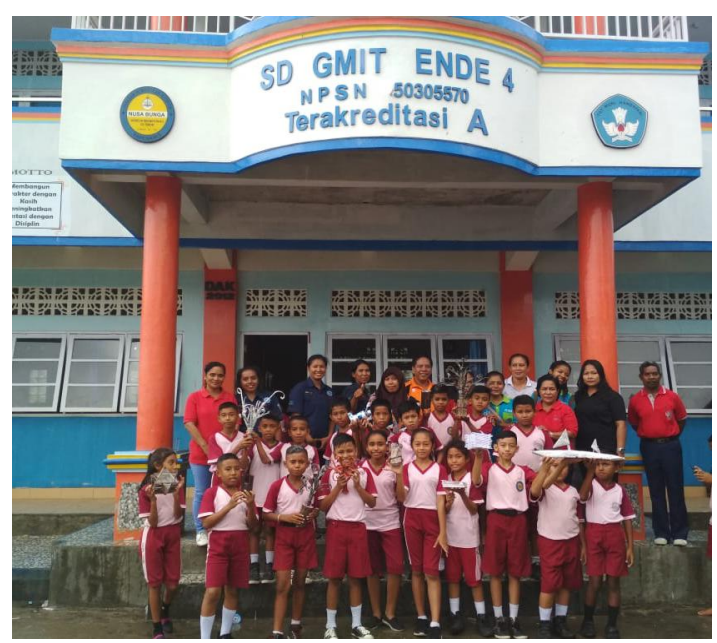

Gambar 3. Foto Bersama Peserta Kegiatan

Adapun Hasil angket mengenai respon peserta kegiatan dapat dilihat pada Tabel 2. terhadap kegiatan tersebut. hal ini terbukti dari rata-rata perolehan angket sebesar $85 \%$.

\section{KESIMPULAN \& SARAN}

Berdasarkan hasil kegiatan disimpulkan bahwa kegiatan ini telah menghasilkan beberapa jenis produk prakarya berbasis sampah kertas di SD GMIT Ende 4. Kegiatan ini juga mendapat respon yang baik dari siswasiswi peserta kegiatan. Saran agar pengetahuan serupa dapat diintegrasikan ke dalam mata pelajaran prakarya. 


\section{DAFTAR PUSTAKA}

Artiningsih, N.K.A. (2008). Peran Serta

Masyarakat dalam Pengelolaan

Sampah Rumah Tangga (Studi Kasus di Sampangan dan Jombang, Kota Semarang). Artikel. Tersedia: eprints.undip.ac.id

Fadhilah dkk. (2011). Kajian Pengelolaan Sampah Kampus Jurusan Arsitektur Fakultas Teknik Universitas Diponegoro. Modul Vol.11 No.2. Tersedia: https://scholar.google.co.id

Hardiyanti, Syamsu dan Roliadi.(2010). Kajian Pengguanaan Selulosa Mikrobial Sebagai Bahan Baku Pembuatan Kertas. Skripsi. Tersedia: repository.ipb.ac.id

Kurniati dan Rizal. (2011). Pemanfaatan Hasil Pengelolaan Sampah Sebagai Alternatif Bahan Bangunan Konstruksi. Artikel. $\begin{array}{lll}\text { Smartek } 9 & 9 \text { (1). } \quad \text { Tersedia: }\end{array}$ Jurnal.untad.ac.id

Suryani, A.S. (2014). Peran bank Sampah dalam Efektfitas Pengelolaan Sampah (Studi Kasus Bank Sampah Malang). Artikel Ilmiah. Aspirasi Vol.5 No. 1. 